\title{
Revenue-Expenditure Nexus for India
}

\author{
Sanhita Sucharita*
}

\begin{abstract}
This paper attempts to find out the inter-temporal relationship between government expenditures and revenues in India. It tries to find out if the variations in revenues cause variations in expenditures or the variation in expenditure cause variation in revenue. It also analyses the trend and composition of rising public expenditure in India. This paper has used vector error correction mechanism to find out the causality between the governments total expenditure and revenue receipt. The empirical analysis suggests long run causality from Government revenue receipts to Government total expenditure. It supports the tax-spend hypothesis that means over time, expenditure decisions are not made in isolation of revenue receipts.
\end{abstract}

Keywords: Government revenue, Government expenditure, Tax spend hypothesis, Cointegration, VECM.

\subsection{Introduction}

India's GDP growth rate has neared to 8 per cent but its sustainability has been in question, first with the 1991 fiscal-balance of payments crisis, and then again after 199798, when fiscal deficits returned to the 10 per cent of GDP range and government debt grew. The combined fiscal deficit of the Centre and the states, which was 9.3 per cent of GDP in the crisis year of 1990-91, dropped to 6.3 per cent in 1996-97 before creeping back up to 9 per cent in 1998-99. The fiscal deficit remained at over 9 per cent until 2002-03 and has since been on a downward shift, declining to 4.2 per cent in 2007-08. Due to the global economic crisis, fiscal deficit increased in 2009-10 to 9.3 per cent. The combined fiscal deficit of the Centre and all States stood at 7.25 per cent of GDP in 2012-13. The study of inter temporal relationship between government expenditures and revenues is important to address fiscal imbalance.

*Assistant Professor (Economics), Centre for Humanities and Social Sciences, School of Humanities and Social Sciences, Central University of Jharkhand, Ranchi. (email: sanhita.sucharita@gmail.com) 
2 | VISION: Journal of Indian Taxation, Volume 3, Issue 1

Persistently large public sector budget deficits have to be eventually corrected through fiscal adjustments in the form of government expenditure cuts and/or tax revenue increases. In India, it is important to know the causality between revenue and expenditure.in order to know which variable should be given priority. It is important to know whether changes in expenditures precede, follow, are independent of, or occur simultaneously with changes in revenues. For example, if expenditure decisions adjust to prior revenue changes, then controlling tax revenues is required to rein in spending and eventually shrink the deficits.

Numerous studies have discussed the connection between government revenues and expenditures. While the views of economists differ on the revenue-expenditure nexus, it has become essential to find out the connection between public expenditure and revenue to have fiscal consolidation. The present paper consists of five sections, including the introduction. Section 2 describes the theoretical base of relation between public expenditure and revenue. Section 3 analyses the trend and composition of public expenditure and revenue of central and state government. Section 4 examines causality between public expenditure and its determinants. Section 5 concludes and summarises the study.

\subsection{Relation between Public Expenditure and Revenue: Theoretical Framework}

The relationship between revenue and expenditure is typically discussed in the literature within the framework of four competing hypotheses, namely the tax-and-spend hypothesis, the spend-and-tax hypothesis, the fiscal synchronization hypothesis, and the institutional separation hypothesis.

\subsection{Tax-Spend hypothesis}

The tax-spent hypothesis states the unidirectional causality running from taxes to spending. Friedman (1978) explained that changes in government revenue bring changes in government expenditure. It is characterised by unidirectional causality running from government revenue to government expenditure. Increasing taxes, increases the cost of available resources for the public sector so as to reduce the budget deficit, will only results in a rise in public expenditure. Ordinarily, if revenue impacts positively on the expenditure, by implication, the decrease in the revenue will lead to a decrease in the expenditure. Friedman noted that increases in tax or revenue will lead to increases in public expenditure. Friedman viewed that raising taxes is not the right way to reduce budget deficit because such adjustment will put pressure on the spending. On the contrary the best solution to reduce budget deficit is tax cutting, which will reduce the 
government expenditure. Buchanan and Wagner $(1977,1978)$ put forward an alternative version of the taxand-spend hypothesis. In contrast to Friedman (1978), they argue that tax increases would lead to spending reductions.

Wagner (1977) Wagner and Buchanan found a negative causal relationship from revenues to expenditures which may exist due to fiscal illusion. Tax cut accentuate the budget deficit. Tax cut stimulates government spending though the perceiving price of public good become lower. It increases the demand for public programs, stimulating the government spending. Buchanan and Wagner (1977) explained deficit financing control is the best way to control public expenditures. Niskanen (2002) explained tax increase may make taxpayers hostile toward government spending as they are forced to directly estimate with its costs. Likewise, tax decreases may lessen the perceived cost of government spending, increasing the quantity demanded.

\subsection{Spend-Tax hypothesis}

Spend-tax hypothesis emphasises the unidirectional causality running from government spending to government taxes. Peacock and Wiseman (1961) explained increases in government expenditures due to economic and political crises (i.e. wars, natural disasters, recessions), can lead to increases in government revenues from taxation, often called the "displacement effect. Government spending drives taxes. The government will start to determine the level of expenditures, which will be followed by adjustments of taxes. During rough times a new higher level of tax is imposed to meet the need of higher public expenditure but once the phenomena are over previous levels of public expenditure and taxation don't return.

Barro $(1974,1979)$ described that higher public spending cause's higher tax. An increase of the government outputs will generate additional taxes. The author rejects the fiscal illusion and expects that the taxpayers fully capitalize the future tax liability.

Furstenberg et al. (1992) explained that spending precedes taxes when the political majority tried to preserve its governance by increasing the expenditures in the preelectoral period. This spending will be financing by additional taxes in the post-electoral period.

\subsection{Fiscal synchronization hypothesis}

Fiscal synchronization hypothesis emphasises on the bidirectional causality between tax and spending. This theory is formulated by Musgrave (1966), and Meltzer and Richard (1981). Musgrave (1966) emphasised on joined decision of government tax and spending taken by policy maker. Under this assumption, in order to decide for 
4 | VISION: Journal of Indian Taxation, Volume 3, Issue 1

appropriate level of taxes and spending, the voters compare the marginal benefits and costs of government programs.

\subsection{Institutional separation hypothesis}

Institutional separation hypothesis states non-causality between government revenues and government expenditures. This theory is formulated by Wildavsky (1988), followed by Baghestani and McNown (1994). Baghestani and McNown (1994) emphasised that there is no relationship between government revenues and government expenditures. This perspective suggests that revenues and expenditures are independent of each other. In this fiscal neutral assumption, each component is given by long-run economic growth, the decisions regarding tax and spending being taken independently. Before doing the empirical analysis on whether variations in revenues cause variations in expenditures or the variation in revenue cause variation in expenditure, it is essential to analysed the trend and composition of revenue and expenditure.

\subsection{Trends and Composition of Central and State Government Expenditure and Revenue}

In a developing economy like India, public expenditure is very much essential to ensure economic growth. Public expenditure means the expenditure made by the Government for the betterment of the public. Public expenditure can promote growth by financing essential public services. Improving the quality and efficiency of public expenditure is very much essential for achieving the optimal growth. In Indian context, there is a consistent increment in both central government and state governments' expenditure together and their aggregate total receipts for the period of 1980-81 to 201314. India has seen tremendous economic growth within these two decades.

\subsection{Trend and composition of central government expenditure and revenue}

After registering a significant fall from 17.3 per cent of GDP in1990-91 to 14.1 per cent of GDP in 2006-07, total expenditure of the central government rose to a level of 15.9 per cent of GDP in 2009-10. In 2015-16 it has again come down to 12.6 per cent of GDP. The total expenditure of Central government comprises of revenue and capital expenditure. The fall in the ratio of total expenditure to GDP came mostly from a reduction in capital expenditure. The quality of expenditure, witnessed deterioration over the years as the share of capital expenditure declined from 5.6 per cent of GDP in 199091 to 1.7 per cent of GDP in 2013-14 (Figure 1). 
Revenue expenditure as a per cent of GDP declined from 12.9 per cent in 1990-91 to 11.6 per cent in 1996-97 and rose thereafter to 13.8 per cent in 2002-03.

Figure 1: Trends in Central Government Expenditures (as a per cent of GDP)

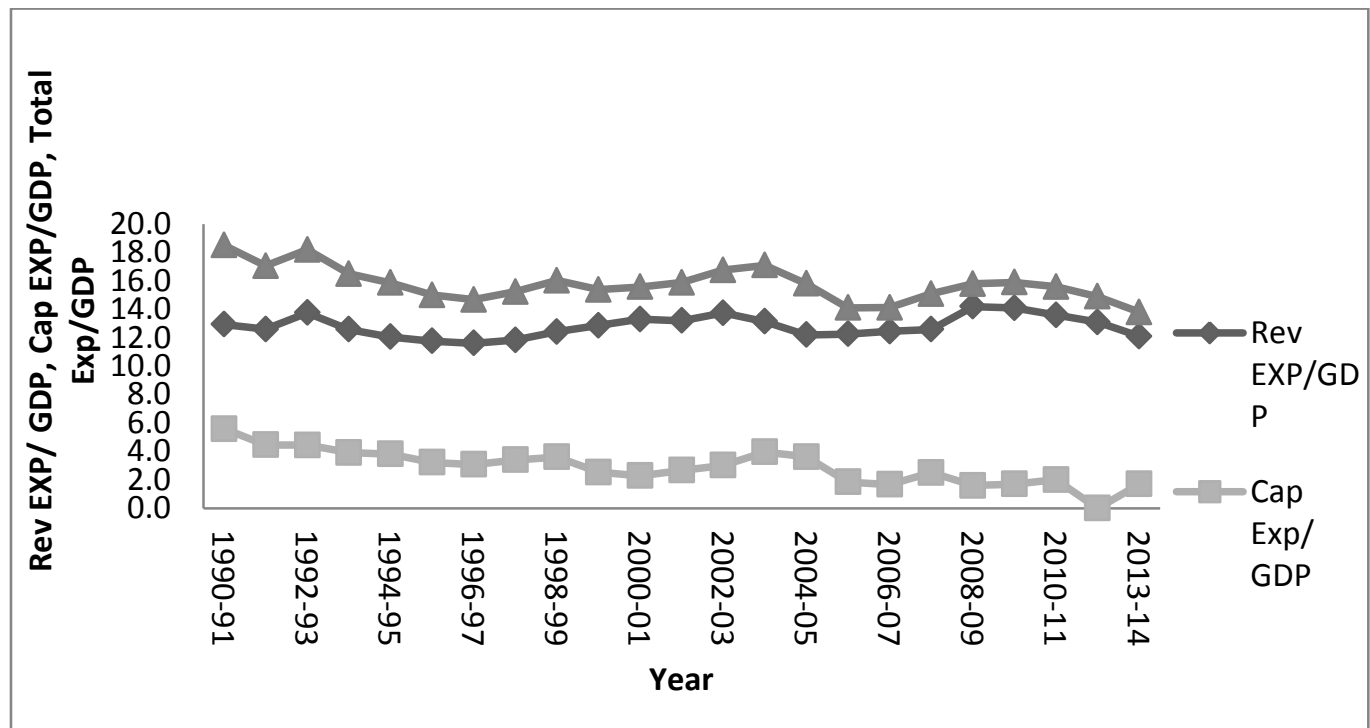

Source: RBI Annual policy Statement, Hand book of statistics on Indian Economy (various issues), Report of the Twelfth Finance Commission, Ministry of Finance, Government of India (2010), Report of the Thirteenth Finance Commission, Ministry of Finance, Government of India.

Expenditure on interest payments, defense, pay and allowances and subsidies are the main components of the Centre's revenue expenditure, accounting for about 63 per cent of the total. While the proportion of expenditure on interest payments to GDP has shown a marginal decline because of the low interest rate regime, expenditure on defense has remained at more than 2 per cent of GDP in almost all the years since 2003-04. Expenditure on explicit subsidies is the third largest item of revenue expenditure after interest payments and defense. Food and fertilizer subsidies are the main explicit subsidies provided by the Centre. (Economic Survey, 2014-15).

In 1990s liberalisation had an adverse impact on tax revenue by reducing tariff rate, custom duties and excise duty (by giving concession to private industry to give them incentive). It also gave concession on direct tax to give incentive to save and invest. In the process of fiscal consolidation among the direct tax both the personal and corporate income taxes, were rationalized. The numbers of rate categories as well as the marginal income tax rates were substantially reduced. The main central commodity 
taxes, union excise duties and custom duties also went under salient changes. In the case of customs duties, there was drastic reduction in the tariff rates across the rate categories. In the case of union excise duties, the principle of taxing the value added was adopted, first in the form of Modified VAT (MODVAT) and later as Central VAT (CENTVAT). The impact of these reforms on direct tax and indirect tax was diametrically opposite. While the direct taxes showed, even with the lower rates a rising tax GDP ratio, this ratio for indirect tax was sliding down. In spite of rationalization of direct tax both personal and corporate income taxes, the fall in the indirect tax to GDP ratio could not be compensated by rise in direct tax.

The tax-GDP ratio of center declined from 10.1 per cent in 1990-91 to 9.23 per cent in 2003-04. In 2007-08 the gross tax-GDP ratio went up to 12.56 per cent by over three per cent in a span of four years (Figure 2). The major contribution to this decline was custom duty. This was basically due to the drastic reduction in tariff rates. This custom duty relative to GDP halved from 3.6 per cent in 1990-91 to 1.8 per cent in 200203. After the enactment of FRBM Act there is a slight improvement observed in the total tax revenue trends. Higher GDP growth coupled with better tax administration and introduction of new taxes such as the 'fringe benefit tax', has resulted in higher growth of tax revenues, particularly from 2004-05.

Figure 2: Central Governments Tax Revenues (as a per cent of GDP)

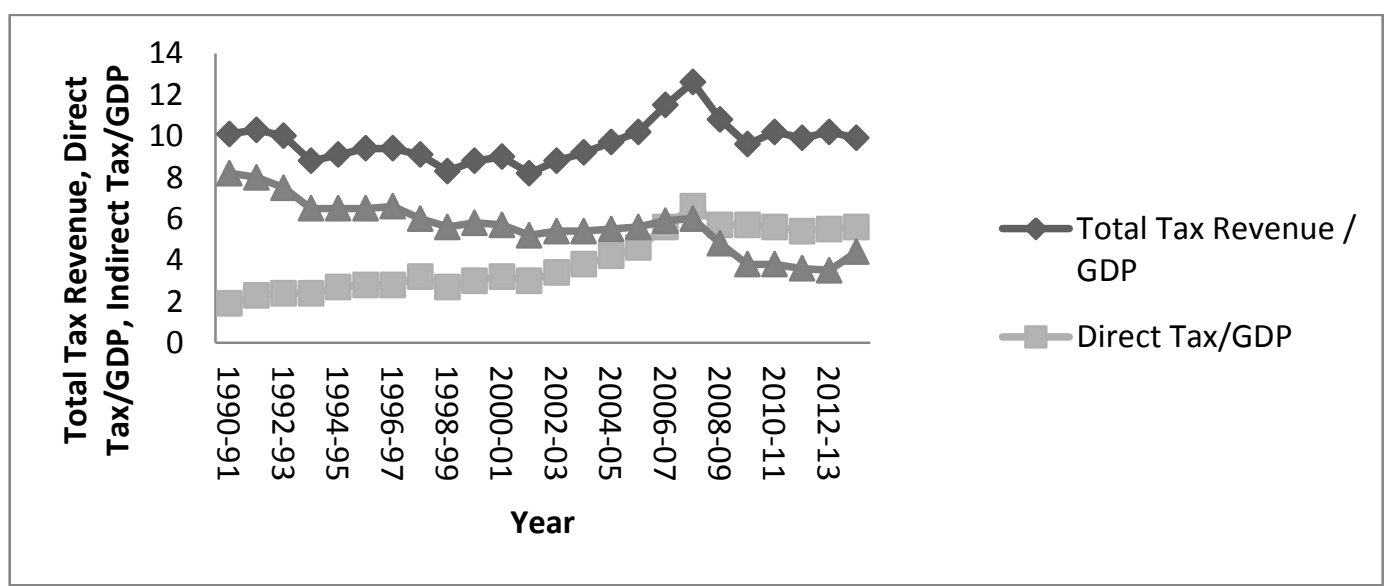

Source: RBI Annual policy Statement (various issues), Handbook of Statistics on Indian Economy, (various issues), Economic Survey (various issues)

The entire improvement came from the buoyancy of direct taxes, more particularly from corporation tax, reflecting the increasing profitability of the Indian corporate sector. In 
fact, indirect tax-GDP ratio has remained stagnant between 5 per cent and 6 per cent since the late nineties. The trend of high growth in tax revenue was reversed in the wake of the global economic crisis in 2008-09. There is a decline in all the taxes. The decline in revenues from all indirect taxes was mainly on account of general economic slowdown, reduction in duty rates (both customs and excise), lower volume of imports of dutiable goods, and various exemptions. The counter-cyclical measures included a duty cut of 4 percentage points in Union excise and 2 percentage points in service tax. As a result, gross tax revenue as percentage of GDP declined from 11.9 per cent in 2007-08 to 9.6 per cent in 2009-10. The additional fiscal space and the tax capacity created since 2003-04 was, therefore, almost entirely wiped out within a span of two financial years. With signs of recovery and partial roll back of stimulus measures given on the indirect taxes front in 2010-11, the tax-GDP ratio recovered marginally to around 10.2 per cent in 2010-11, only to fall to 9.9 per cent in 2011-12. While it again increased marginally to 10.2 per cent in 2012-13,

\subsection{Aggregate States' revenue receipt and expenditure}

States' revenue receipts consists of tax receipts and non-tax receipts Again tax receipts consists of own tax revenue and share in central taxes. Non tax revenue consists of non-tax revenue and grants from the Centre. States' own aggregate revenues receipts divided in own tax and own non tax. States authority to raise direct taxes is limited to agriculture income tax and profession tax. States have larger space in indirect tax field with power to tax goods at the point of sale (except in the course of interstate sale and import-export) and duties of excise on liquor and intoxicants being with them. In terms of wealth and assets taxation, states have authority to tax properties and land.

The total revenue receipts to GDP ratio declined from 11.6 per cent in 1990-91 to 9.9 per cent in 1998-99, after which it showed a little improvement. There was significant improvement in total revenue receipts of states by 1.71 per cent of GDP, between 2004-05 and 2007-08. While all the components of revenue receipts contributed to this improvement, the primary contributors were transfers from the centre followed by own tax revenues. There was improvement in all the components of revenue receipts of states between 2004-05 and 2007-08. Among the states total receipts the slowest growing item was the transfers from the centre. The current transfer from centre came down from 4.7 per cent of GDP in 1990-91 to 3.6 per cent of GDP in 1998-99. Share in central taxes, improved significantly considerably following the recommendations of Eleventh Finance Commission, further improved in the award period of Twelfth Finance Commission. Share in central taxes as a per cent of GDP went up from 2.49 per cent in 2004-05 to 3.22 per cent in 2007-08. The ratio of own 
tax revenues to GDP for all states fell from 5.3 per cent in 1993-94 to 4.9 per cent in 1998-99 and was at 5.1 per cent in 1999-00. Own tax revenues as a proportion of GDP improved to 6.07 per cent in 2007-08 which is the highest so far. Most aggregate indicators of revenue receipts on the whole showed improvement till 2007-08 and deterioration thereafter, for 2008-09 and 2009-10. The trend seems to have reversed again from 2010-11, with revenue receipts showing significant increases. 4.15. The States' aggregate 'own revenues' (the sum total of 'own tax revenues' and 'own non-tax revenues'), as a percentage of GDP, showed an upward trend, increasing from 7.0 per cent in 2004-05 to 7.6 per cent in 2012-13.The aggregate revenue receipts, including aggregate own revenues and aggregate transfers from the Union, showed an overall increasing trend (except in 2008-09 and 2009-10), from about 11.2 per cent of GDP in 2004-05 to nearly 12.4 per cent in 2012-13 (Figure 3).

Figure 3: Aggregate States' Revenue Receipts (as a per cent of GDP)

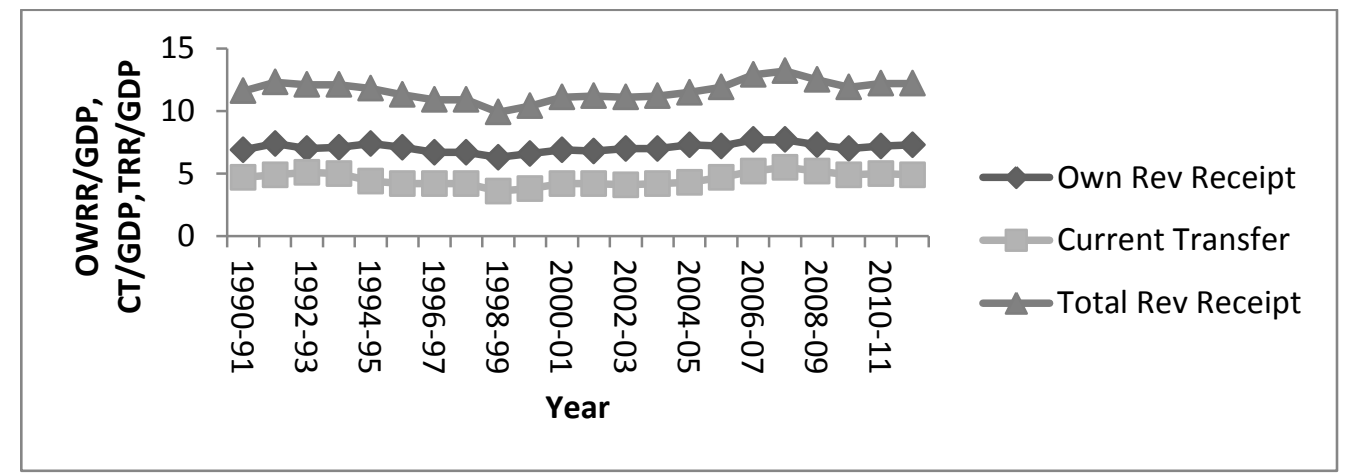

Source: RBI Annual policy Statement (various issues), Handbook of Statistics on Indian Economy, (various issues), Economic Survey (various issues)

Post-FRBM period shows that in the years preceding the global crisis, revenue-led consolidation was largely driven by central transfers in the low income states. States' own revenues played a dominant role in high and middle income states. Besides own tax revenues (OTR), own non-tax revenue (ONTR), particularly from state lotteries and various user charges contributed significantly to the reduction in Primary Deficit in some of these states. States' revenue efforts would be complemented by the award of the Fourteenth Finance Commission which seeks to expand autonomy of states within the ambit of fiscal federalism by stepping up statutory transfers through untied tax devolution, reduction of discretionary plan grants and improvements in the design of transfers (State Finances: A Study of Budgets of 2014-15). 
In contrast to the trend in revenue receipts, almost all expenditure categories have shown faster growth. These increases were particularly sharp in the case of interest payments and pensions. As far as interest payments were concerned, it rose from about 1.82 per cent in 1993-94 to 2.96 per cent in 2002-03. In the case of pension also, there was a sharp rise from 0.691 per cent of GDP in 1993-94 to 1.24 per cent of GDP in 2002-03.

The Plan revenue expenditure came down from 2.22 per cent of GDP in 199394 to 1.81 per cent of GDP in 2002-03. It was on account of interest payments and pension that the total revenue expenditure showed a rising trends and it has increased from 11.41 per cent of GDP in 1993-94 to 13.06 per cent of GDP in 2002-03. In contrast to growth in revenue receipts, all the components of revenue expenditure, with the exception of plan revenue expenditure, have exhibited a declining trend in the period 2004-05 to 2007-08 Total revenue expenditure as a per cent of GDP declined from 12.74 per cent in 2004-05 to 12.26 per cent in 2007-08. Within total revenue expenditure, while non-plan expenditure witnessed a sharp decline from 10.85 per cent to 9.88 per cent, plan expenditure increased from 1.89 per cent to 2.39 per cent in the same period. During this period, revenue expenditure declined by 0.47 per cent of GDP largely on account of decline in interest payments by 0.63 per cent of GDP. Interest payments moderated from 2.75 per cent of GDP in 2004-05 to 2.12 per cent in 200708 . This decline can be attributed to the interest relief obtained by states from the Debt Consolidated Relief Fund, amounting to Rs. 15,689 crore over the period 2005-09. The debt swap scheme, which was operational during 2002-05 also contributed to the reduction in interest payments. An amount of Rs. 1, 02,034 crore of high-cost debt was swapped under the scheme, resulting in savings in interest payments for states. It may, however, be difficult to sustain the reduction in revenue expenditure because of the pay revisions. A number of states have revised pay scales of employees in the light of the recommendations of the Sixth CPC. Karnataka and Kerala revised their pay scales in 2007 and 2004, respectively. The increase in plan revenue expenditure of states is on account of increased transfers through centrally Sponsored Schemes.

Aggregate capital expenditure of states registered improvement in the period 200405 to 2007-08 following reduction in revenue expenditure and the surplus on revenue account in the years 2006-07 and 2007-08. Between 2004-05 and 2007-08, the aggregate capital expenditure of states went up by 0.59 per cent of GDP. Expenditureled fiscal consolidation during the pre-crisis period has been achieved essentially through reduction in revenue expenditure. Post-crisis expenditure-led fiscal 
consolidation was seen in six states, all of which also witnessed an increase in revenue receipts during the consolidation year.

\subsection{Methodology and Results}

RBI Handbook of Statistics data on revenue receipts and expenditures for the combined central and state governments from 1980-81 to 2013-14 have been used in this study. The data have also been transformed into natural logs. All the variables are considered in their natural logarithmic form and denoted by the suffix ' $\mathrm{LN}$ ' and are explained below. The theoretical model is a two variable the total government expenditure and total government revenue receipts. Two major variables are such that each serves as dependent and independent variable. In this case,

$\mathrm{E}=\mathrm{f}(\mathrm{R})$, therefore, $\mathrm{E}=\gamma 0+\alpha \mathrm{R}+u_{1}$

$\mathrm{R}=\mathrm{f}(\mathrm{E})$, therefore, $\mathrm{R}=\gamma^{\sim} 0+\alpha^{\sim} \mathrm{E}+u_{2}$

$\mathrm{E}=$ Total Government (central and state governments together) Expenditure

$\mathrm{R}=$ Total Government (central and state governments together) Revenue receipts

$u_{1}$ and $u_{2}=$ normally distributed error term

\subsection{Stationarity test}

In empirical analysis, non-stationarity of time series data is a perennial problem. To avoid estimating and getting spurious results, the study conducted tests for stationarity. The three variables specified in the model were assumed to have a trend and unit root. The variables were tested for the existence of unit roots in level, in first difference and in second difference. In order to measure the stationarity, the study used Augmented Dickey Fuller test (ADF). The reason for using ADF is that it gets rid of serial correlation. To do this, we tested for Unit root of variables. The ADF test is estimated by the following regression:

Given an observed time series Y1 Y2 ... $Y_{N}$ Dickey and Fuller consider three differentialform autoregressive equations to detect the presence of a unit root:

$$
\begin{gathered}
\Delta E_{t}=\delta E_{t-1}+\sum_{i-1}^{n} \alpha_{i} \Delta E_{t-1}+u_{t} \\
\Delta E_{t}=\beta_{1} \beta_{2} \mathrm{t}+\delta E+\sum_{i-1}^{n} \alpha_{i} \Delta E_{t-1}+u_{t} \\
\Delta E_{t}=\beta_{1}+\beta_{2} \mathrm{t}+\delta E_{t-1}+\sum_{i-1}^{n} \alpha_{i} \Delta E_{t-1}+u_{t}
\end{gathered}
$$

where $t$ is the time index,

$\beta_{1}$ is an intercept constant called a drift,

$\beta_{2}$ is the coefficient on a time trend,

$\delta$ is the coefficient presenting process root, i.e. the focus of testing,

$n$ is the lag order of the first-differences autoregressive process, 
$u_{t}$ is an independent identically distributes residual term.

Focus of testing is whether the coefficient $\gamma$ equals to zero, which means that the original E1 E2 $\ldots E_{N}$ process has a unit root; hence, the null hypothesis of $\gamma=0$ (random walk process) is tested against the alternative hypothesis $\gamma<0$ of stationarity. If the variables, when run through ADF happen to be integrated of order Zero, I(0) i.e. they are stationary in the first test will indicate that the variable affects the Public expenditure in the short run. Conversely if ADF happen to be I(1) ,I(2) I(3) etc., it will mean that the variables have a lag length and this indicates that they affect the model in the long run and requires a co-integration test.

Augmented Dickey-Fuller (1979) unit root tests (Table 1) fail to reject a unit root for expenditures, revenue receipt and population series. For their first differences however, the unit root hypothesis can be easily rejected. All the variables are nonstationary at levels and stationary at first-differences. This leads to the conclusion that all the variables are I(1), which prompts us to use Johansen's technique to test for integration between the variables. They are non-stationary but when converted to first difference they became stationary. When Variable is integrated of same order we can run the Johansen test of cointegration.

Table 1: Stationary and Unit Root test

\begin{tabular}{|c|c|c|c|}
\hline Variable & Level & First Difference & Second Difference \\
\hline $\mathrm{E}$ & -2.434210 & -9.486070 & -6.443639 \\
\hline $\mathrm{R}$ & -0.113097 & -5.894031 & -9.131253 \\
\hline
\end{tabular}

\subsection{Determination of lags}

The optimum lag length of the model is determined by Schwartz Information Criterion (SBC), which is of order one. All the variables are found to have trend in level but not in first difference. Hence, we chose unrestricted intercept and no trend option in determining the number of co-integrating vectors among the variables.

\subsection{Cointegration test}

Cointegration rank (rank of matrix) is estimated using Johansen methodology. Johansen's approach derives two likelihood estimators for the CI rank: a trace test and a maximum Eigen value test. The test results are based on maximum eigen value and trace 
of the stochastic matrix, respectively. In the table the trace statistics is not greater than the critical value so we cannot reject the null hypothesis. The null hypothesis is there is no integration. In Table 2, part two represents the Eigen value is greater than the critical value so we reject the null hypothesis. The test results indicate the presence of one integrating vectors among the variables. The co-integration equation represent long run equilibrium relation between $\mathrm{E}$ and $\mathrm{R}$. The presence of cointegration between variables suggests a long term relationship among the variables under consideration. Then, the VEC model can be applied.

Table 2: Testing of co-integration between $E$ and $R$

\begin{tabular}{|c|c|c|c|c|}
\hline $\begin{array}{l}\text { Null } \\
\text { Hypothesis }\end{array}$ & $\begin{array}{l}\text { Alternative } \\
\text { Hypothesis }\end{array}$ & Trace Statistic & $95 \%$ Critical Value & $\mathrm{p}$ value \\
\hline \multicolumn{5}{|c|}{ Trace Statistic } \\
\hline $\mathrm{r}=0$ & $\mathrm{r}>=1$ & 15.43782 & 15.49471 & 0.0510 \\
\hline $\mathrm{r}<=1$ & $\mathrm{r}>=2$ & 0.003755 & 3.841466 & 0.9499 \\
\hline \multicolumn{5}{|c|}{ Maximum Eigen value Test } \\
\hline $\mathrm{r}=0$ & $\mathrm{r}=1$ & 15.43407 & 14.26460 & 0.0325 \\
\hline $\mathrm{r}<=1$ & $r=2$ & 0.003755 & 3.841466 & 0.9499 \\
\hline
\end{tabular}

Granger (1988) points out that if there exists a cointegrating vector among variables, there must be causality among these variables at least in one direction. Granger (1986) and Engle and Granger (1987) provide a test of causality that takes into account information provided by the cointegrated properties of variables. Though there is one cointegration vector among variable and there is long run relationship among the variable so we can apply VECM model to find out the causality between expenditure and revenue.

\subsection{VECM Model for testing the causality between public expenditure and revenue} Given the variables are cointegrated, it is appropriate to use a vector error-correction framework (Table 3).

$\Delta E t=\gamma 0+\alpha 1 \Delta \mathrm{E} t-1+\ldots+\alpha p \Delta \mathrm{E} t-p+\beta 1 \Delta R t-1+\ldots+\beta \rho \Delta R t-p+\rho \varepsilon^{\wedge} t-1+u t$

$\Delta \mathrm{R} t=\gamma^{\sim} 0+\alpha^{\sim} 1 \Delta E t-1+\ldots+\alpha^{\sim} p \Delta E t-p+\beta^{\sim} 1 \Delta R t-1+\ldots+\beta^{\sim} \rho \Delta R t-p+\rho^{\sim} \varepsilon^{\wedge} t-1+\tilde{u^{2} t}$ 
where $\varepsilon^{\wedge} t$ is the period $t$ estimated residual from the integrating relationship.

Table A3: Estimated VECM for E and R

\begin{tabular}{|l|l|l|}
\hline Regressor & $\mathbf{D}(\mathbf{E})$ & $\mathbf{D}(\mathbf{R})$ \\
\hline CointEqn & -0.602185 & -0.128071 \\
& {$[-4.56699]$} & {$[-0.55907]$} \\
& & \\
\hline $\mathrm{D}(\mathrm{E})(-1)$ & 0.030388 & -0.011943 \\
& {$[0.20613]$} & {$[-0.04663]$} \\
\hline $\mathrm{D}(\mathrm{E})(-2)$ & 0.228561 & -0.065844 \\
& {$[1.56052]$} & {$[-0.25876]$} \\
\hline $\mathrm{D}(\mathrm{R})(-1)$ & -0.418273 & -0.299838 \\
& {$[-2.79823]$} & {$[-1.15458]$} \\
\hline $\mathrm{D}(\mathrm{R})(-2)$ & -0.318829 & -0.416689 \\
& {$[-2.32978]$} & {$[-1.75261]$} \\
\hline
\end{tabular}

\section{System equation}

$\mathrm{D}(\mathrm{E})=\mathrm{C}(1) *(\mathrm{E}(-1)-0.9733639242 * \mathrm{R}(-1)-0.6009936571)+\mathrm{C}(2) * \mathrm{D}(\mathrm{E}(-1))+$ $\mathrm{C}(3) * \mathrm{D}(\mathrm{E}(-2))+\mathrm{C}(4) * \mathrm{D}(\mathrm{R}(-1))+\mathrm{C}(5) * \mathrm{D}(\mathrm{R}(-2))+\mathrm{C}(6)$

$\mathrm{D}(\mathrm{R})=\mathrm{C}(7) *(\mathrm{E}(-1)-0.9733639242 * \mathrm{R}(-1)-0.6009936571)+\mathrm{C}(8) * \mathrm{D}(\mathrm{E}(-1))+$ $\mathrm{C}(9) * \mathrm{D}(\mathrm{E}(-2))+\mathrm{C}(10) * \mathrm{D}(\mathrm{R}(-1))+\mathrm{C}(11) * \mathrm{D}(\mathrm{R}(-2))+\mathrm{C}(12)$

In Table 4, $\mathrm{C} 1$ is $(-0.602185)$ negative and $\mathrm{P}(0.0001)$ is significant, so Revenue Receipt has long run causality with Expenditure. There exists long run causality from revenue receipt to government expenditure. It support tax and spend hypothesis. Variation in revenue is increasingly important in explaining future expansion in expenditure.

Table A4: VECM Coefficient

\begin{tabular}{|l|c|c|c|}
\hline & Coefficient & $\mathrm{T}$ & $\mathrm{P}$ \\
\hline $\mathrm{C}(1)$ & -0.602185 & -4.566992 & 0.0001 \\
\hline $\mathrm{C}(2)$ & 0.030388 & 0.206130 & 0.8384 \\
\hline $\mathrm{C}(3)$ & 0.228561 & 1.560517 & 0.1312 \\
\hline $\mathrm{C}(4)$ & -0.418273 & -2.798229 & 0.0098 \\
\hline $\mathrm{C}(5)$ & -0.318829 & -2.329776 & 0.0282 \\
\hline
\end{tabular}




\begin{tabular}{|l|l|l|l|}
\hline $\mathrm{C}(6)$ & 0.197535 & 4.934609 & 0.0000 \\
\hline
\end{tabular}

From the Wald test (Appendix Table A) we found that $\mathrm{p}$ is $0.01 \%$ which is less than $5 \%$. So, we can reject the null hypothesis meaning that there is short run causality from revenue to expenditure. Wald statistics result shows that in the short run all the revenue lag variables jointly influence government expenditure.

\subsection{Conclusion}

The VECM model suggest over time expenditure decision are not made in isolation of revenue receipts. It is recommended, as first step, to determine the public inputs, followed by adjustments in the level of public spending. India is following a procyclical fiscal policy.Government is choosing to increase public spending and reduce taxes during an economic boom, but reduce spending and increase taxes during a recession. Lack of strong institution is the main cause of procyclicality. Under this scenario, the government of India during boom should try to raise revenue and cut expenditure to control fiscal deficit in India. The effectiveness of fiscal policy can be enhanced by making budget expenditure less driven by revenue availability. Expenditure rule is essential for India though it directly aimed at addressing the expenditure pressures often at the origin of excessive deficits, they are transparent and generally easy to monitor, they fully accommodate revenue shortfalls resulting from adverse economic shocks (allowing for a stabilizing role of fiscal policy), and it is most directly related to the formulation of the annual budget, which sets legally binding appropriations, thus contributing to the rules' enforceability. Importantly, and unlike deficit caps, expenditure rules also help creating buffers in good times, when revenue windfalls can make spending pressures difficult to resist.

\section{References}

Anderson, W., Wallace, M. S. \& Warner, J. T. (1986). Government spending and taxation: what causes what?. Southern Economic Journal, 52(3): 630-639.

Buchanan, J., Wagner, R. (1977). Democracy in Deficit: The Political Legacy of Lord Keynes. New York: Academic Press.

Friedman, M. (1978). The limitation of tax limitation. Policy Review, 5, 7-14. 
Wagner, R. E. (1976). Revenue structure, Fiscal Illusion and Budgetary Choice. Public Choice, spring, 30-61.

Kanayo, O \& Terifa, W.A (2012). Testing the relationship between Government Revenue and Expenditure: Evidence from Nigeria. International Journal of Economics and Finance, 4(12).

Saka,j.o , Lawal,A. , Kareem, S.D., , Babalola, S. J. (2015) Is Fiscal Synchronization Hypothesis Valid for Nigeria? Evidence from Disaggregated Data (1961-2013). American Journal of Economics, 5(3): 337-346.

Young, A. (2009). “Tax-Spend or Fiscal Illusion?”. Cato Journal, 29(3).

\section{Appendix}

Table A: Wald Test

\begin{tabular}{|l|c|l|c|}
\hline Test Statistic & Value & df & Probability \\
\hline F-statistic & 4.475686 & $(2,25)$ & 0.0218 \\
\hline Chi-square & 8.951372 & 2 & 0.0114 \\
\hline
\end{tabular}

